\title{
VIDERE MAJUS QUIDDAM ${ }^{1}$
}

(рецензія на монографію Соболь В. Українське бароко. Тексти і контексти. - Warszawa: Wydawnictwa Uniwersytetu Warszawskiego, 2015. - 382 c.)

Валентина Соболь - один із найцікавіших сучасних медієвістів, численні публікації якої охоплюють широке коло проблем давньої української літератури. Варто лишень згадати окремі книги вченого, що засвідчують глибину і високий професіоналізм ії наукової практики. Це монографії «Літопис Самійла Величка як явище українського літературного бароко» (Донецьк, 1996), «12 подорожей в країну давнього письменства» (Донецьк, 2003), «Пам'ятна книга Дмитра Туптала» (Варшава, 2004), навчальні книги «3 глибини віків» (Київ, 1995; Кам'янець-Подільський, 2002), «Не будьмо тінями зникомими» (Донецьк, 2006) і серія підручників «До джерел» для українських ліцеїв у Польщі (Варшава, 2005, 2006, 2007). 2015 року видавництво Uniwersytetu Warszawskiego опублікувало ще одну монографію - «Українське бароко: Тексти і контексти», де авторка в притаманній йй манері поєднує глибокий аналіз текстів давньої української літератури з філігранним викладом матеріалу.

Рецензована книга має складну, добре скомпоновану структуру. Архітектонічний рівень представлено передовсім вдало оформленою палітуркою, на якій відтворено гравюру «Києво-Могилянська академія та іiі вихованці» (XVII ст.). Дизайн видання позбавлений очікуваної барокової пишноти і барвистості. Це руйнування сподіваного, безсумнівно, налаштовує на серйозний інтелектуальний і водночас захоплюючий діалог про яскраву i суперечливу літературну епоху, що залишила цікаві тексти, таємничі коди яких осягатиме відповідно до своїх зацікавлень кожне покоління читачів. Формальний рівень книги доповнюють стримані елементи зовнішнього оформлення; це здебільшого чорно-білі ілюстрації, серед яких переважають фрагменти сторінок друкованих книг, рукописних діаріушів і живописних полотен. Шмуцтитул 3 назвою першого розділу містить цитату зі статті Леоніда Ушкалова, яку можна вважати епіграфом до всієї праці: «... Вітчизняне письменство XI-XVIII століть на сьогодні є справжньою Атлантидою, чиїх обширів, єства та ролі в нашій духовній традиції до пуття не знає ніхто [...]. Часом один-однісінький 3-поміж тих творів, як от, приміром, фундаментальна «Книга житій святих» Дмитра Туптала, годен перевернути обсягом ледь не всю українську літературу першої половини XIX століття купно взяту». На третій сторінці палітурки подано стислу інформацію про саму авторку, на четвертій - кілька цитат Богдани Криси, Michała Łesiowa й Ігоря Набитовича з рецензій на рукопис книги.

Окремо варто сказати про прояв особистісного начала в науковому дискурсі Валентини Соболь, засвідчений на зворотньому боці титулу книги інтровертною присвятою: «Моїм онукам Олесі, Артемові». Займенник «моїм» посилює емоційність фрази, а в поєднанні 3 іменами адресатів актуалізує особистісні смисли і наділяє їх додатковою інтимною виразністю.

${ }^{1}$ Videre majus quiddam (лат.) - Щоб побачити щось більше.

(C) I. C. Руснак 
Внутрішня організація простору книги відзначається взаємозв'язаністю: матеріал розподілено на три розділи з різною кількістю підрозділів. Досить розлогий Вступ налаштовує реципієнта на сприйняття результату кропітких багаторічних досліджень складних літературних комплексів не менш складної епохи. Це грунтовне і глибоке дослідження української літературної спадщини бароко в контексті відображення ментальності й історії людської повсякденності. Новочасний підхід, як зауважує сама авторка, покликаний до життя тією обставиною, що «українська література XVI-XVIII століть варта того, аби 3 іншої перспективи подивитися на звичне та, здавалося б, давно усталене». У Вступі науковець задекларувала свою дослідницьку стратегію, прикметною рисою якої є поєднання традиційних з новаторськими підходами до грунтовної інтерпретації українських барокових текстів. Цементують різні методологічні стратегії антропологічні практики, які активно розвиваються в сучасному літературознавстві, зокрема і польському. Тож симптоматично, що монографія Валентини Соболь побачила світ саме у варшавському видавництві.

Не оминула авторка можливості сказати кілька слів про структуру своєї книги, що нагадує своєрідний ансамбль, композиційну єдність якого і забезпечує обрана методологія. Назви розділів і підрозділів книги в лапідарній формі відображають узагальнений зміст основного тексту. Також Валентина Соболь коротко, за ііі висловом, «пунктирно» подала огляд джерел, де історикоантропологічний підхід до українських творів давньої доби став основним.

Відразу впадає в око, що монографія - не вузьке літературознавче дослідження, а складний історико-культурно-мистецький комплекс, де історична, культурологічна, а також релігійно-етична складові мають внутрішню єдність і цілісність. Тут наявний глибокий аналіз творів, серед яких основне місце займають не класичні зразки українського бароко, а маловідомі пам'ятки. Серед них твори, опрацьовані авторкою в архівах Варшави, Парижа і Москви, зокрема польськомовний анонім «Преславна Гора Почаївська», копія діаріуша Пилипа Орлика анонімних польських палеографів, рукопис діаріуша Пилипа Орлика, діаріуш Дмитра Туптала. Не залишилися поза увагою і твори Данила Братковського, Василя Григоровича-Барського, Климентія Зіновієва, анонімні тексти, козацькі літописи тощо.

Вражає підготовлений з особливою ретельністю джерелознавчий апарат наукової студії, де подано об'ємну бібліографію (більше 300 позицій), що допомагає глибоко зануритися в обрану історико-літературну проблему. Книгу оснащено Додатком «Видання барокових творів», Іменним покажчиком i Покажчиком творів, які відіграють роль надійних орієнтирів у просторі наукового видання, значно полегшуючи його рецепцію.

Наукове сумління зобов'язало дослідницю зазначити в «Бібліографічній довідці», які студії вперше опубліковані в книзі, а які своєю основою мали виступи на наукових конференціях різних рівнів, проте в процесі написання монографії зазнали серйозного допрацювання. Резюме українською, польською й англійською мовами містять короткий виклад головної ідеї й основного змісту наукової праці. 
Змістовий рівень книги сформовано семантикою надрукованого у ній тексту. У першому розділі «Ad Fontes. Контекстуальний простір украӥнського бароко» основна увага зосереджена на осмисленні ситуації, що склалася в Україні та за іiі межами довкола дослідження українського бароко. Перший підрозділ має досить об'ємний формат, однак залучене тут широке коло наукових джерел засвідчує достеменне знання авторкою досліджуваної проблеми. Цікавими видаються твердження щодо різновекторності наукових студій про українське бароко, які, доповнюючись навчально-педагогічною практикою, розгорталися головно в науково-дослідному, видавничому, перекладацькому й інших форматах. Заслуговує на увагу пропозиція щодо особливостей вивчення українського бароко в загальноосвітній і вищій школах, де посутніми мають стати праці Миколи Зерова, Агапія Шамрая, Юрія Шевельова і Дмитра Чижевського. Другий підрозділ являє собою ретельну наукову рецепцію праць Івана Франка про давнє українське письменство. Головною тезою $є$ твердження про те, що в студіях над літературою українського бароко мисленик реалізував власну настанову щодо історії української літератури як «образу духовного розвою нації». Третій підрозділ присвячено цілісному осмисленню видавничої діяльності братств, що здійснено в історико-порівняльному контексті. Валентина Соболь грунтовно проаналізувала погляди українських, італійських, польських i російських учених на братства як своєрідний культурно-історичний феномен доби бароко. Вичерпний аналіз питання дав можливість зробити висновок про видавничу діяльність братств як головний фактор українського культурного відродження. Останній підрозділ цікавий інтерпретацією барокових українських панегіриків про книгу, науку й освіту. Міркування авторки про жанрову природу панегіриків суголосні 3 думками багатьох учених. Ïї спостереження над окремими творами дають можливість усвідомити, що тема науки, освіти і книги була однією з найважливіших у літературі зрілого бароко і (що особливо цінно) залишається актуальною для розуміння неперебутності гуманістичних цінностей у наші дні.

Другий розділ під назвою «Феномен барокової історіографії: образ ментальності та історія повсякденного життя» занурює реципієнта в жанрове розмаїття барокових текстів. У першому підрозділі авторка інтерпретує козацькі літописи, в яких особливо виразно постає історія крізь вимір приватного життя. Погляд на козацьке літописання крізь призму приватності дозволив дати досить переконливі відповіді на численні питання, пов'язані з дискурсом Церкви і релігійних взаємин у добу бароко. Слушною $є$ заувага дослідниці щодо органічного поєднання історії, політики і релігії в барокових текстах, їхнього зв'язку 3 традиційною риторикою, глибоким ліризмом, прагненням вести живий діалог із читачем. Довершена інтерпретація польськомовної пам'ятки про чудотворну ікону в другому підрозділі перетворилася на результативну стратегію «розговорити» анонімний твір, провести його переконливий опис i детальний текстологічний аналіз. Особливий інтерес викликає третій підрозділ з інтерпретацією «власноручної літератури» (Ф. Ар’єс), авторство якої належить Йоасафові Горленку, Пилипові 
Орлику гербу Новина, Дмитрові Тупталу і Каролеві Хоєцькому гербу Любіч. У центрі наукових розмислів - аскетизм і любов до самотності як одна 3 підставових прикмет приватності. Кожне барокове джерело авторка розглядає як унікальне і самодостатнє явище в усьому комплексі можливих детермінант, які вплинули на формування того чи іншого тексту, віднесеного в монографії до жанру перієгез. Вигідно вирізняються з-поміж інших два наступні підрозділи розвідки, де крізь призму літературної імагології та приватності осмислено концепти одягу і сну. Вбрання, залишаючись елементом приватного світу людського буття, актуалізує, на думку дослідниці, вічні проблеми і вічні образи. Натомість сон виконує у бароковому тексті кілька функцій, серед яких найважливішими є застереження, покара і передвіщення.

Третій розділ «Перекладна література українського бароко» складається 3 двох підрозділів, у яких розглядаються різножанрові перекладні тексти зрілого i пізнього бароко відповідно. Унікальний пласт барокових текстів, будучи своєрідним мостом між Сходом і Заходом, на думку авторки, дає можливість з'ясувати глибинні джерела європейськості української літератури. Валентина Соболь переконливо довела, що переклади Леона Кішки, Порфирія Важинського, Василя Попеля, Григорія Сковороди, Тимофія Щуровського і багатьох інших дають можливість відстежити особливості повсякденного буття давньої епохи в його локальному вимірі, національних і психологічних проявах. Дискурс приватності західноєвропейських культур, засвідчено в розділі, органічно узвичаювався в українській бароковій культурі, яка активно демонструвала свою відкритість, надавав їй нових імпульсів. Скрупульозне студіювання цього літературного пласту дозволило науковцю окреслити низку важливих проблем, зокрема потребу аналізу стародруків і рукописів про санктуарії та чудодійні ікони, вивчення мови пам'яток, спостережень змін у царині зображення приватності у давніх тектах, а головне - сучасних підходів у вивченні перекладної літератури доби бароко.

Висновки в монографії чіткі й аргументовані: зовнішні контакти бароко були багатовекторні; подолавши національні бар'єри, бароко оприсутнило українство у європейському культурному просторі. Ключові тези можна звузити до заключного акорду монографії Валентини Соболь: «Якщо буде написана історія приватного життя на українському матеріалі (як це зробили в п'яти томах французькі вчені на французькому матеріалі), то барокова сторінка в цій історії постане в красі і мудрій силі».

Думаю, важливо зауважити смислову точність, об'єктивність і строгість, які визначають науковий стиль авторки, що подекуди органічно поєдналися 3 прихованою емоційністю (наприклад, ледь відчутною тривогою через безповоротну втрату примірників пам'ятки в роздумах про «Преславну Гору Почаївську»; неприйняттям негативних змін, інспірованих царською Росією в XVIII ст., у підрозділі про перекладну літературу зрілого бароко тощо). Емоційно забарвлені фрагменти справляють враження більш об'ємних, дозволяють їм довше зберігатися в пам'яті реципієнта.

Монографія «Українське бароко. Тексти і контексти» розрахована не тільки на літературознавців, котрі займаються проблемами медієвістики, а й на 
широке коло читачів. Літературне бароко віддалене від сучасного реципієнта в часі та просторі, але, як усяке минуле, незримо прокладає мости в теперішність. Тож videre majus quiddam у сьогоденності, ми кожного разу повинні повертатися до своїх духовних витоків. I книга Валентини Соболь у цьому безкінечному процесі - безцінний путіник.

Ірина Руснак, Київський університет імені Бориса Грінченка 